\title{
X-ray Structure Refinement and Vibrational Spectroscopy of $\mathrm{Ca}_{8} \mathrm{Gd}_{2}\left(\mathrm{PO}_{4}\right)_{6} \mathrm{O}_{2}$
}

\author{
R. Ayadi, M. Boujelbene* and T. Mhiri
}

Laboratory of the Physico-Chemistry of Solid States. LR11 ES51. of Sfax. Road of Soukra km 4. Sfax3071. Tunisia.

Email: rayda_ayadi @yahoo.fr

M. Boujelbene

Laboratory of the Physico-Chemistry of Solid States. LR11 ES51. of Sfax. Road of Soukra km 4. Sfax3071. Tunisia.

*Corresponding author: m_boujelbene2010 @yahoo.fr

T. Mhiri

Laboratory of the Physico-Chemistry of Solid States. LR11 ES51. of Sfax. Road of Soukra km 4. Sfax3071. Tunisia.

Email: tahermhiri@yahoo.fr

\section{Abstract}

The present paper is interested in the study of compounds from the apatite family with the general formula $\mathrm{Ca}_{10}\left(\mathrm{PO}_{4}\right)_{6} \mathrm{~A}_{2}$. It particularly brings to light the exploitation of the distinctive stereochemistries of two Ca positions in apatite. In fact, GdBearing oxyapatite $\mathrm{Ca}_{8} \mathrm{Gd}_{2}\left(\mathrm{PO}_{4}\right)_{6} \mathrm{O}_{2}$ has been synthesized by solid state reaction and characterized by X-ray powder diffraction. The site occupancies of substituents is 0.3333 in $\mathrm{Gd}$ and 0.3333 for $\mathrm{Ca}$ in the $\mathrm{Ca}(1)$ position and 0.5 for $\mathrm{Gd}$ in the $\mathrm{Ca}$ (2) position. Besides, the observed frequencies in the Raman and infrared spectra were explained and discussed on the basis of unit-cell group analyses.

KEYWORDS: Inorganic compounds; X-ray diffraction; Infrared spectroscopy; Raman spectroscopy.

\section{Council for Innovative Research}

Peer Review Research Publishing System

\section{Journal: Journal of Advances in Chemistry}

Vol. 5, No. 2

editor@cirworld.com

www.cirworld.com, member.cirworld.com 


\section{Introduction}

The structure of apatite $\mathrm{Ca}_{10}\left(\mathrm{PO}_{4}\right)_{6} \mathrm{~A}_{2}, \mathrm{~A}=\mathrm{F}, \mathrm{OH}, \mathrm{O}, \mathrm{Cl}, \ldots$ apatite in the space group $\mathrm{P} 6_{3} / \mathrm{m}$ allows a wide range of cation substitution [1-16].

A compact arrangement of $\mathrm{PO}_{4}$ tetrahedrons constitutes the skeleton of this structure which exhibits two kinds of tunnels parallel to the c-axis.

The first is occupied by four $M(1)$ cations at $4 \mathrm{f}$ sites, along a three -fold axis. These cations are coordinated by nine oxygen atoms. The second tunnel which is the larger is occupied, on its periphery, by the six other M (2) cations at $6 \mathrm{~h}$ sites, along a six-fold axis. These $\mathrm{M}(2)$ cations which are surrounded by six oxygen atoms and one $\mathrm{Y}$ atom two alternated equilateral triangles at level $1 / 4$ and $3 / 4$ centred on a six - fold axis where the $\mathrm{Y}$ atoms are located.

The formula assigned to the compound had to be $\left[\mathrm{Ca}_{4}\right]^{4 \mathrm{f}}\left[\mathrm{Ca}_{4.4} \mathrm{Bi}_{1.6}\right]^{6 \mathrm{~h}}\left(\mathrm{PO}_{4}\right)_{6}\left[\mathrm{O}_{1.8}\right]^{2 \mathrm{a}}$ with space group $\mathrm{P} 6_{3} / \mathrm{m}$. Thus the lower oxygen content (1.8) compared to stoichiometric expected(2) (see the procedure), confirmed the volatilized of bismuth. Therefore, $16 \%$ de bismuth was volatilized. The refined results indicated that the $\mathrm{Bi}^{3+}$ ions were mainly located in $\mathrm{Ca}(2)$ site on $6 \mathrm{~h}$ position and formed two triangles that rotated $60^{\circ}$ from the c-axis. The oxygen atom $\mathrm{O}_{4}$ was located in the center of these Bi-triangles [17].

The compounds $\mathrm{Bi} \mathrm{Ca}_{4}\left(\mathrm{PO}_{4}\right)_{3} \mathrm{O}$ and $\mathrm{La} \mathrm{Ca}_{4}\left(\mathrm{PO}_{4}\right)_{3} \mathrm{O}$ have been reported recently [18]. They are isostructural with $\mathrm{Bi} \mathrm{Ca}_{4}$ $\left(\mathrm{VO}_{4}\right)_{3} \mathrm{O}$ [19]. Which is closely related to the apatite structure except for the number of cationic sites available. $\mathrm{Bi} \mathrm{Ca}_{4}$ $\left(\mathrm{VO}_{4}\right)_{3} \mathrm{O}$ crystallizes in hexagonal symmetry with space group P63/m have only two types of cationic sites [20,21] where as $\mathrm{Bi} \mathrm{Ca}_{4}\left(\mathrm{VO}_{4}\right)_{3} \mathrm{O}$ is reporter to have three types of cationic sites viz; $\mathrm{Ca}(1), \mathrm{Ca}(2)$ and $\mathrm{Ca}(3)$. The formula can be written as $\mathrm{Ca}(1)_{0.9} \mathrm{Bi}(1)_{0.1} \mathrm{Ca}(2)_{2.1} \mathrm{Bi}(2)_{0.9} \mathrm{Ca}(3)\left(\mathrm{VO}_{4}\right)_{3} \mathrm{O}$. The $\mathrm{Ca}(1)$ and $\mathrm{Ca}(3)$ atoms occupy $2 \mathrm{~b}$ and $\mathrm{Ca}(2)$ occupies $6 \mathrm{c}$ crystallographic sites. Both $\mathrm{Ca}(1)$ and $\mathrm{Ca}(2)$ atoms have 6 - fold coordination and $\mathrm{Ca}(3)$ atom has 9 -fold coordination with

respect to oxygen. $\mathrm{Ca}(2)$ has an irregular hexa- coordinated polyhedron and the $\mathrm{O}(3)$ atom in the coordination sphere does not belong to any of the $\mathrm{PO}_{4}$ groups $\mathrm{Bi}$ atom occupies both $\mathrm{Ca}(1)$ and $\mathrm{Ca}(2)$ sites with more occupancy in the low symmetry $\mathrm{Ca}(2)$ site.

In the present work, we propose to investigate the structure of the phosphate apatite and the vibrational spectroscopy of the $\mathrm{Ca}_{8} \mathrm{Gd}_{2}\left(\mathrm{PO}_{4}\right)_{6} \mathrm{O}_{2}$ compound.

\section{Experiment}

The $\mathrm{Ca}_{8} \mathrm{Gd}_{2}\left(\mathrm{PO}_{4}\right)_{6} \mathrm{O}_{2}$ compound was obtained by the solid-state reaction of $\mathrm{Gd}_{2} \mathrm{O}_{3}$ (Merck. 98. 9\%), $\mathrm{P}_{2} \mathrm{O}_{5}$ (Merck. 98. 9\%) and $\mathrm{CaCO}_{3}$ (Cerac. 99.95\%), as shown in the following formula:

$$
\mathrm{Gd}_{2} \mathrm{O}_{3}+3 \mathrm{P}_{2} \mathrm{O}_{5}+8 \mathrm{CaCO}_{3} \rightarrow \mathrm{Ca}_{8} \mathrm{Gd}_{2}\left(\mathrm{PO}_{4}\right)_{6} \mathrm{O}_{2}+8 \mathrm{CO}_{2} \text { (gaz) }
$$

The resultant powder was subsequently heated at $740^{\circ} \mathrm{C}$ during $12 \mathrm{~h}$, in slow cooling conditions

X-ray powder diffraction (XRD) pattern was determined by means of a Panalytical XPERT PRO MPD diffractometer equipped with a detector X'cellerator operating with a secondary monochromator and using a CuKa radiation source (Ka ${ }_{1}$ $=0.15439 \mathrm{~nm}$ and $\mathrm{Ka}_{2}=0.15440 \mathrm{~nm}$ ). The diffraction pattern was recorded under ambient atmosphere over an angular range of $5-80^{\circ}(2 \theta)$ with a step length of $0.033^{\circ}(2 \theta)$.

The Fourier transform infrared (FT-IR) measurements were performed at room temperature. On a JASCO FT-IR 420 spectrometer over the $4000-400 \mathrm{~cm}^{-1}$ region, in a $\mathrm{KBr}$ pellet. Furthermore, Raman spectra were measured with a LABRAMHR 800 triple monochromatic at room temperature under a $50 \times$ LF objective microscope, a He-Ne ion laser operating at about $300 \mathrm{~mW}$ was used (on the triple) as an excitation source $\left(514.532 \mathrm{~nm}\right.$ ), with a spectral steps of $3 \mathrm{~cm}^{-1}$.

\section{Results and discussion}

\subsection{Refinement of the structure}

The structure of the compounds in the solid are closely related to those of the common phosphate apatite. They have been frequently described in the literature [22]. They have been commonly determined by X-Ray powder diffraction using the Rietveld method refinement stating from the isostructural phase $\mathrm{Ca}_{10}\left(\mathrm{PO}_{4}\right)_{6} \mathrm{~F}_{2}$.

The analysis of the final adjustments carried out for the observed and calculated diagrams indicated that there were nonindexed lines. The latter could be identified as minor impurities. The latter could be identified as $\mathrm{Ca}_{3}\left(\mathrm{PO}_{4}\right)_{2}$.

The final results of this refinement are presented in Table. 1, Table. 2 (for the structure parameters), Table. 3 (for the atomic positions) and Table. 4 (the bond length distances and angles). Besides Fig. 1 shows the observed, calculated and different X-ray profiles of the powder diffraction of these apatite phosphates. 
Table. 1. Details of powder $X$ - ray data collection and structure refinement of $\mathrm{Ca}_{8} \mathrm{Gd}_{2}\left(\mathrm{PO}_{4}\right)_{6} \mathrm{O}_{2}$.

\begin{tabular}{|l|l|}
\hline Formula & $\mathrm{Ca}_{8} \mathrm{Gd}_{2}\left(\mathrm{PO}_{4}\right)_{6} \mathrm{O}_{2}$ \\
\hline Halfwidth parametres & $\mathrm{U}=0.019711$ \\
& $\mathrm{~V}=-0.052960$ \\
& $\mathrm{~W}=0.035341$ \\
\hline Parametres asymetry & Asy1 $:-0.02951$ \\
& Asy $2:-0.01187$ \\
\hline Reliability Factors & $\mathrm{R}_{\mathrm{F}}: 0.055$ \\
& $\mathrm{R}_{\mathrm{B}}: 0.1152$ \\
& $\mathrm{R}_{\mathrm{P}}: 0.132$ \\
& $\mathrm{R}_{\mathrm{WP}}: 0.133$ \\
\hline
\end{tabular}

Table. 2. Analytical data and lattice parameters of $\mathrm{Ca}_{8} \mathrm{Gd}_{2}\left(\mathrm{PO}_{4}\right)_{6} \mathrm{O}_{2}$.

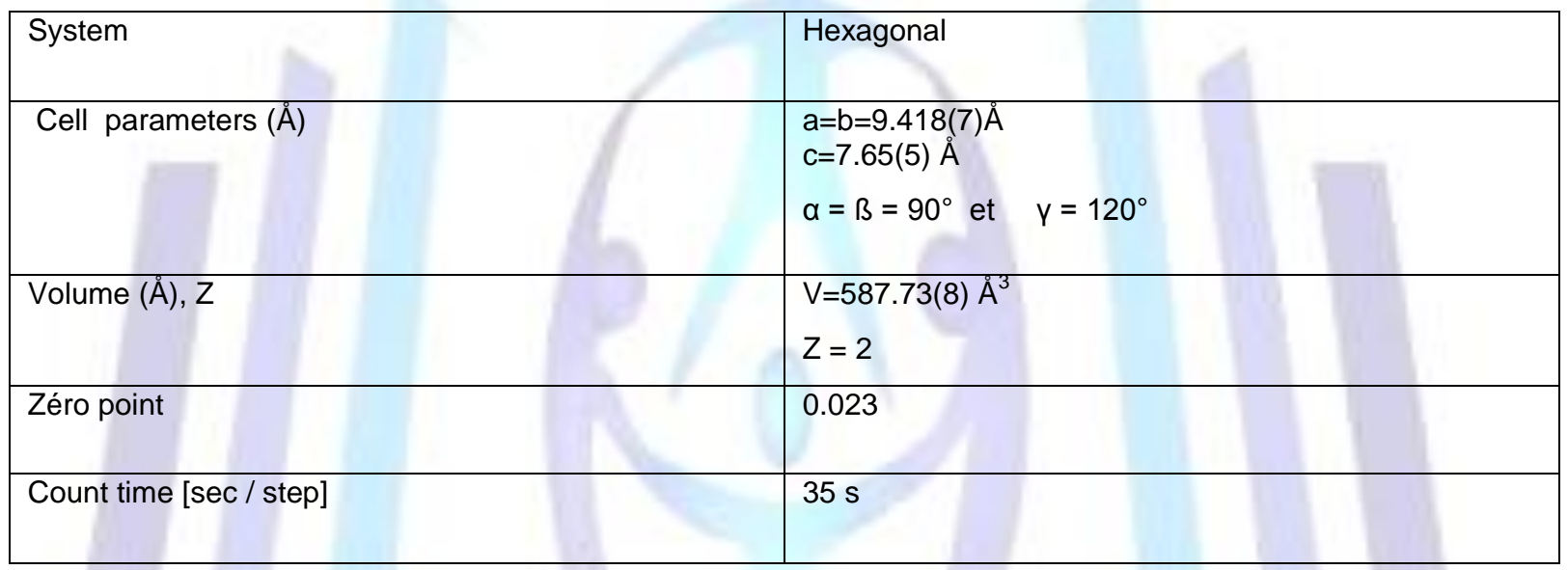

Table. 3. Atomic coordinates, occupancy factors after Riveted refinement of $\mathrm{Ca}_{8} \mathrm{Gd}_{2}\left(\mathrm{PO}_{4}\right)_{6} \mathrm{O}_{2}$

\begin{tabular}{|l|l|l|l|l|l|}
\hline Atom & $\mathrm{X}$ & $\mathrm{Y}$ & $\mathrm{Z}$ & Ueq & $\mathrm{B} \exp$ \\
\hline $\mathrm{Ca}(1)$ & $1 / 3$ & $2 / 3$ & $-0.00096(4)$ & $0.01426(19)$ & $1 / 3$ \\
\hline $\mathrm{Gd}(1)$ & $1 / 3$ & $2 / 3$ & $-0.00096(4)$ & $0.01426(19)$ & $1 / 3$ \\
\hline $\mathrm{Ca} \mathrm{(2)}$ & $0.01231(9)$ & $1 / 4$ & $1 / 4$ & $0.0401(2)$ & 0.5 \\
\hline $\mathrm{Gd}(2)$ & $0.01231(9)$ & $1 / 4$ & $1 / 4$ & $0.0401(2)$ & 0.5 \\
\hline $\mathrm{P}$ & $0.39224(4)$ & $0.36716(5)$ & $1 / 4$ & $0.0350(13)$ & 0.5 \\
\hline $\mathrm{O}(1)$ & $0.3499(9)$ & $0.4975(9)$ & $1 / 4$ & $0.0075(11)$ & 0.5 \\
\hline $\mathrm{O}(2)$ & $0.5969(9)$ & $0.4688(7)$ & $1 / 4$ & $0.0075(11)$ & 0.5 \\
\hline $\mathrm{O}(3)$ & $0.34489(5)$ & $0.26913(5)$ & $0.07354(8)$ & $0.0075(11)$ & 0.5 \\
\hline $\mathrm{O}(4)$ & 0.00000 & 0.00000 & $0.32595(10)$ & $0.0075(11)$ & $1 / 3$ \\
\hline
\end{tabular}


Table. 4. Selected bond lengths $\left(A^{\circ}\right)$ and bond angles $\left(^{\circ}\right)$ in $\mathrm{Ca}_{8} \mathrm{Gd}_{2}\left(\mathrm{PO}_{4}\right)_{6} \mathrm{O}_{2}$.

\begin{tabular}{|l|l|}
\hline Atom & Bond lengths $(\AA \AA)$ \\
\hline $\mathrm{Ca}(1)-\mathrm{O}_{2}$ & $2.556(4)$ \\
\hline $\mathrm{Ca}(1)-\mathrm{O}_{3}$ & $2.836(5)$ \\
\hline $\mathrm{Ca}(1)-\mathrm{O}_{1}$ & $2.550(4)$ \\
\hline $\mathrm{Ca}(1)-\mathrm{O}_{1}$ & $2.547(6)$ \\
\hline $\mathrm{Ca}(1)-\mathrm{O}_{3}$ & $2.836(5)$ \\
\hline $\mathrm{Ca}(1)-\mathrm{O}_{2}$ & $2.556(5)$ \\
\hline $\mathrm{Ca}(1)-\mathrm{O}_{2}$ & $2.553(5)$ \\
\hline $\mathrm{Ca}(1)-\mathrm{O}_{3}$ & $2.832(5)$ \\
\hline $\mathrm{Ca}(2)-\mathrm{O}_{3}$ & $2.600(5)$ \\
\hline $\mathrm{Ca}(2)-\mathrm{O}_{2}$ & $2.403(4)$ \\
\hline $\mathrm{Ca}(2)-\mathrm{O}_{3}$ & $2.600(8)$ \\
\hline $\mathrm{Ca}(2)-\mathrm{O}_{3}$ & $2.687(8)$ \\
\hline $\mathrm{Ca}(2)-\mathrm{O}_{3}$ & $2.687(8)$ \\
\hline $\mathrm{Ca}(2)-\mathrm{O}_{4}$ & $2.372(8)$ \\
\hline
\end{tabular}

\begin{tabular}{|c|c|c|c|}
\hline Atoms & Bond lengths $(\dot{A})$ & Angles $\left(^{\circ}\right)$ & \\
\hline $\mathrm{P}-\mathrm{O}_{1}$ & $1.451(4)$ & $\mathrm{O}_{3}-\mathrm{P}-\mathrm{O}_{2}$ & $104.12(8)$ \\
\hline $\mathrm{P}-\mathrm{O}_{2}$ & $1.583(6)$ & $\mathrm{O}_{3}-\mathrm{P}-\mathrm{O}_{3}$ & $118.85(9)$ \\
\hline $\mathrm{P}-\mathrm{O}_{3}$ & $1.557(3)$ & $\mathrm{O}_{3}-\mathrm{P}-\mathrm{O}_{1}$ & 109.71(5) \\
\hline $\mathrm{P}-\mathrm{O}_{3}$ & $1.557(3)$ & $\mathrm{O}_{2}-\mathrm{P}-\mathrm{O}_{1}$ & $109.81(8)$ \\
\hline
\end{tabular}

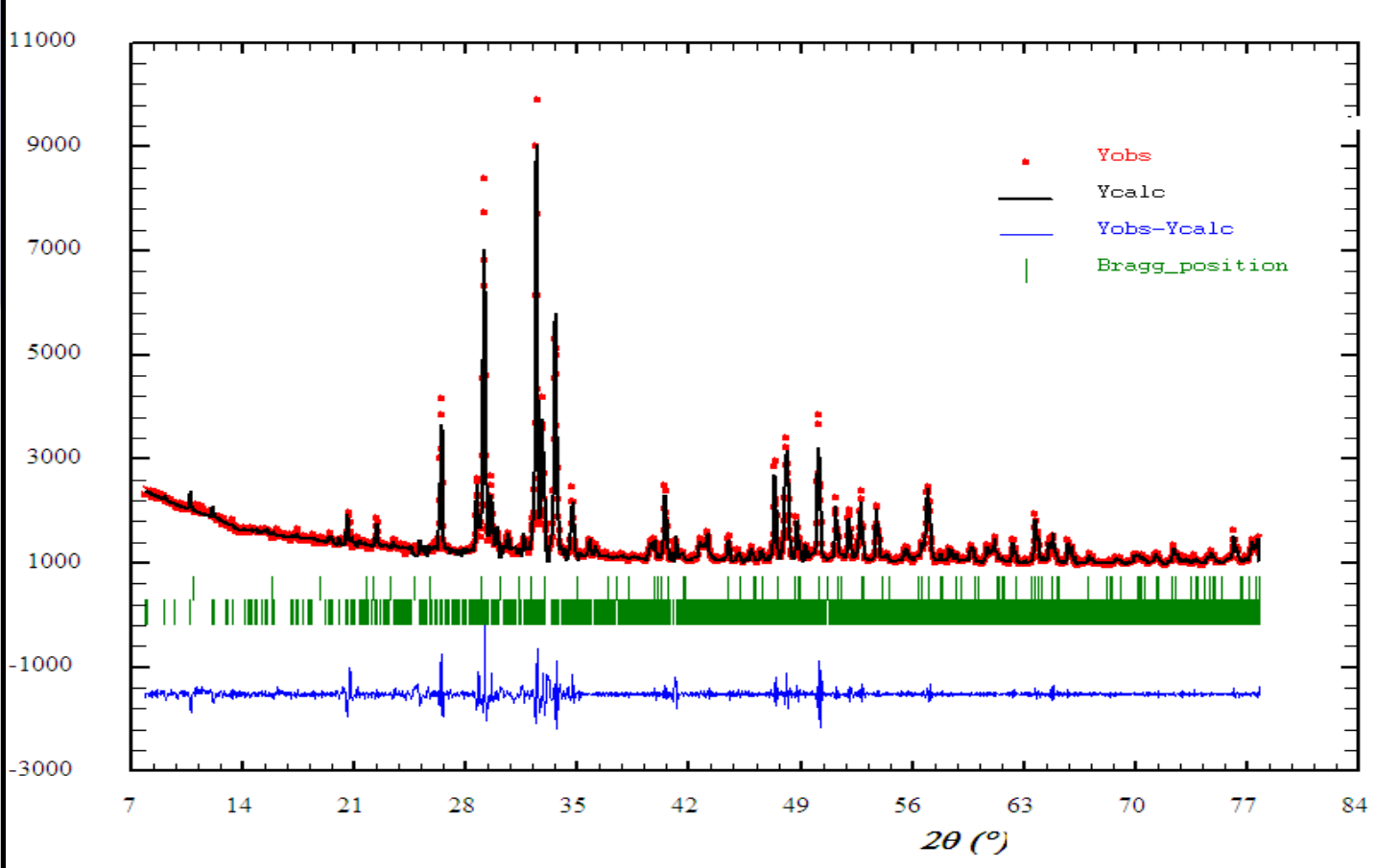

Figure. 1. The final Rietveld refinement plot of the $\mathrm{Ca}_{8} \mathrm{Gd}_{2}\left(\mathrm{PO}_{4}\right)_{6} \mathrm{O}_{2}$. 


\subsection{Discussion}

Fig. 2. as shows the analysis of the tetrahedra revealed that the average P-O distance (1.537 (5) $\AA$ ) is nearly the same than the average values observed in oxyapatite $(1.535(4) \AA)$. The angles O-P-O were, on the other hand varied between $104.12^{\circ}$ and $118.85^{\circ}$, with an average value $\left(109.71^{\circ}\right)$. This is very close to the one of a uniform tetrahedron $\left(109.47^{\circ}\right)$.

The cations $M$ (1) (Ca1/Gd1) were coordinated to nine oxygen anions belonging to six distinct tetrahedral. Each polyhedron was linked to three $\mathrm{PO}_{4}$ tetrahedra via corners and to three other tetrahedra via edges (Fig. 3.). The M (2) $(\mathrm{Ca} 2 / \mathrm{Gd} 2)$ cations are inserted into six -fold sites that constituted the walls of the tunnels. Each polyhedron was linked to four $\mathrm{PO}_{4}$ tetrahedra via corners and to one $\mathrm{PO}_{4}$ via edge and two of the free oxygen $\mathrm{O}_{4}$ (Fig. 4.).

In the case of the M (1)-O distances, the nine distances have an average value of $2.658(5) \AA$. which is slightly larger than the one observed in calcium-Fluorapatite $(2.414(13) \AA)$. In the case of the $M(2)-O$ distances, the average value is $2.558(4) \AA$, which is similar than in calcium Fluorapatite $2.535(12) \AA$ [23].

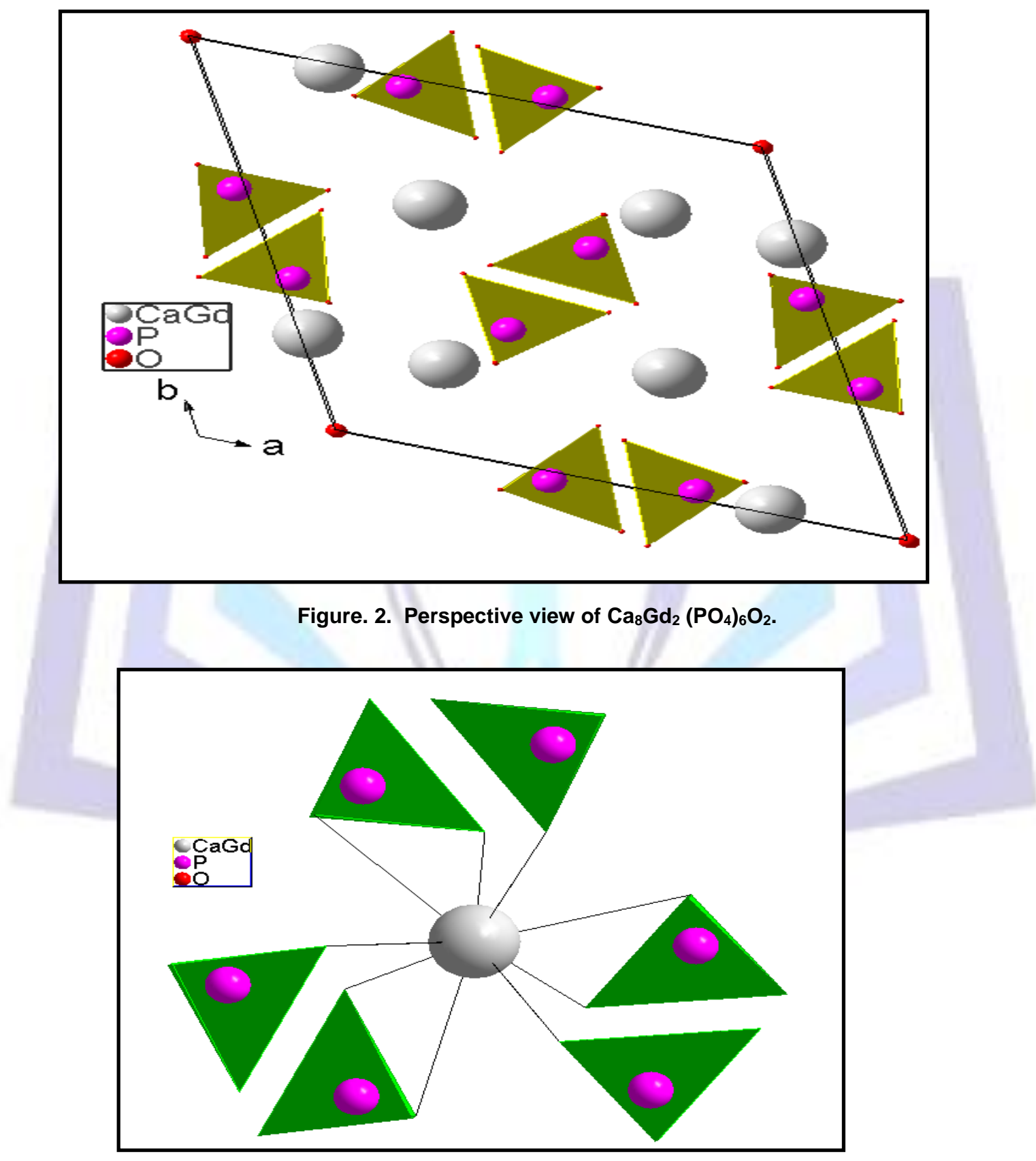

Figure.3. Coordination of the metal M (1). 


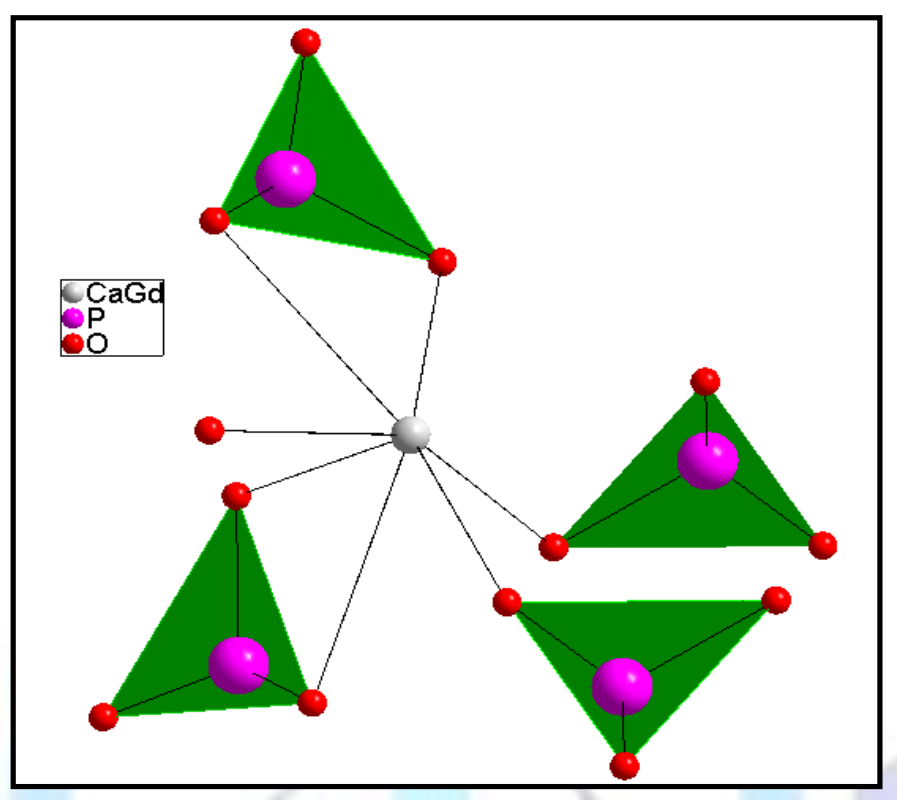

Figure.4. Coordination of the metal M (2).

\section{Spectroscopy analysis}

The IR and Raman spectra are shown in Fig. 5 and Fig. 6 respectively. The spectral data and proposed vibration assignment is listed in Table. 5. As shown in the Raman spectrum. One strong band at $963 \mathrm{~cm}^{-1}$, was observed, which can be attributed to $v_{1}\left(\mathrm{PO}_{4}\right)$. The position of these bands were similar to those $\left(933\right.$ and $\left.963 \mathrm{~cm}^{-1}\right)$ previously reported by Toumi [24]. The weaker peaks observed at 1040, 1058 and $1082 \mathrm{~cm}^{-1}$ and those recorded at 539,607 and $642 \mathrm{~cm}^{-1}$ which can be accredited to the asymmetric stretching $\mathrm{v}_{3}$ and the asymmetric bending modes $\mathrm{v}_{4}$ of $\mathrm{PO}_{4}$ groups, respectively. They were observed at $575 / 600 \mathrm{~cm}^{-1}$ and at $545 / 575 \mathrm{~cm}^{-1}$ in $\mathrm{Pb}_{10}\left(\mathrm{PO}_{4}\right)_{6} \mathrm{~F}_{2}$ and $\mathrm{Ca}_{10}\left(\mathrm{PO}_{4}\right)_{6} \mathrm{~F}_{2}$ [25], respectively. Regarding the weak lines observed at 432 and $445 \mathrm{~cm}^{-1}$. They could be assigned to the symmetric bending $\mathrm{v}_{2}$ mode.

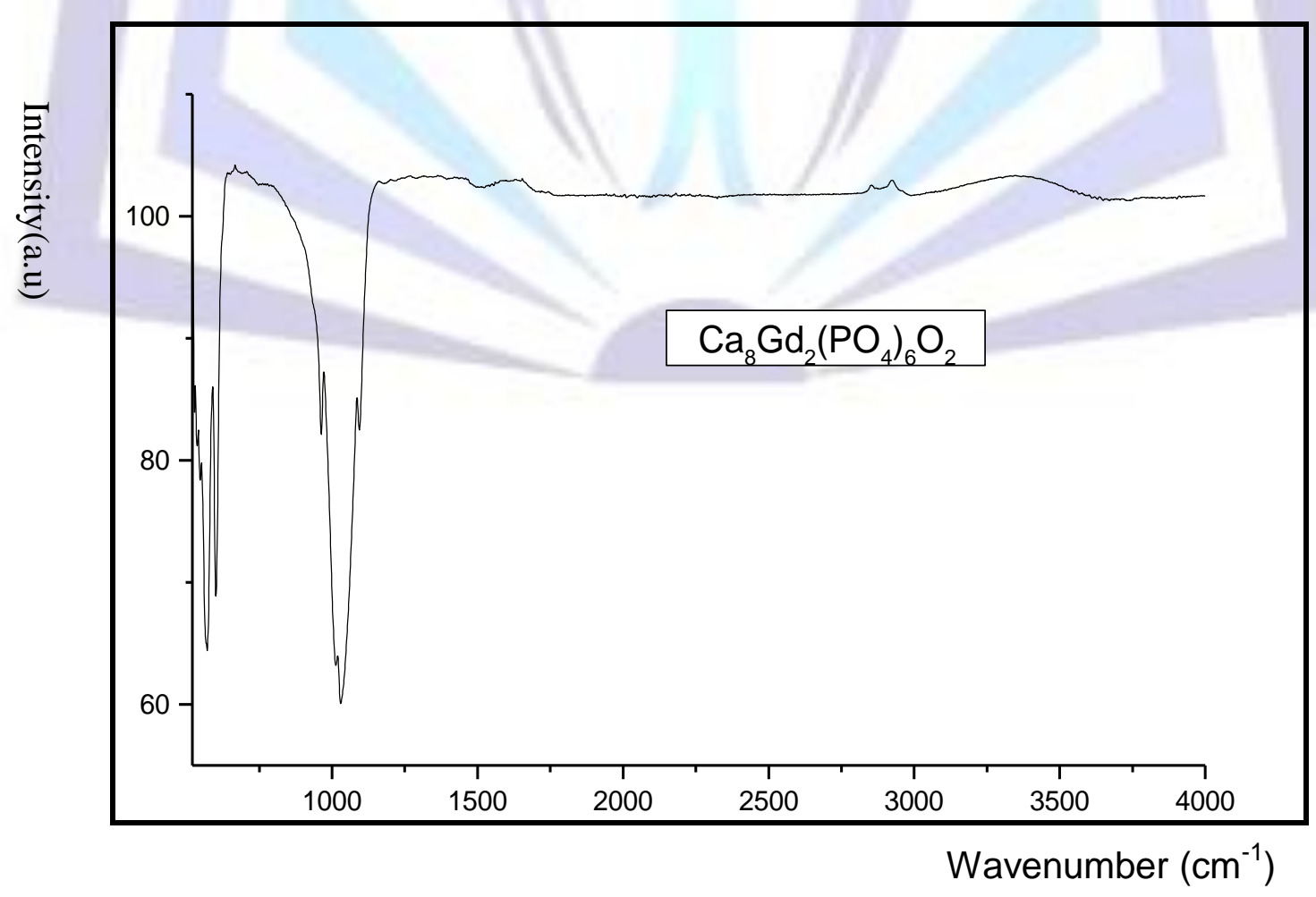

Figure. 5. Infrared spectrum of $\mathrm{Ca}_{8} \mathrm{Gd}_{2}\left(\mathrm{PO}_{4}\right)_{6} \mathrm{O}_{2}$. 


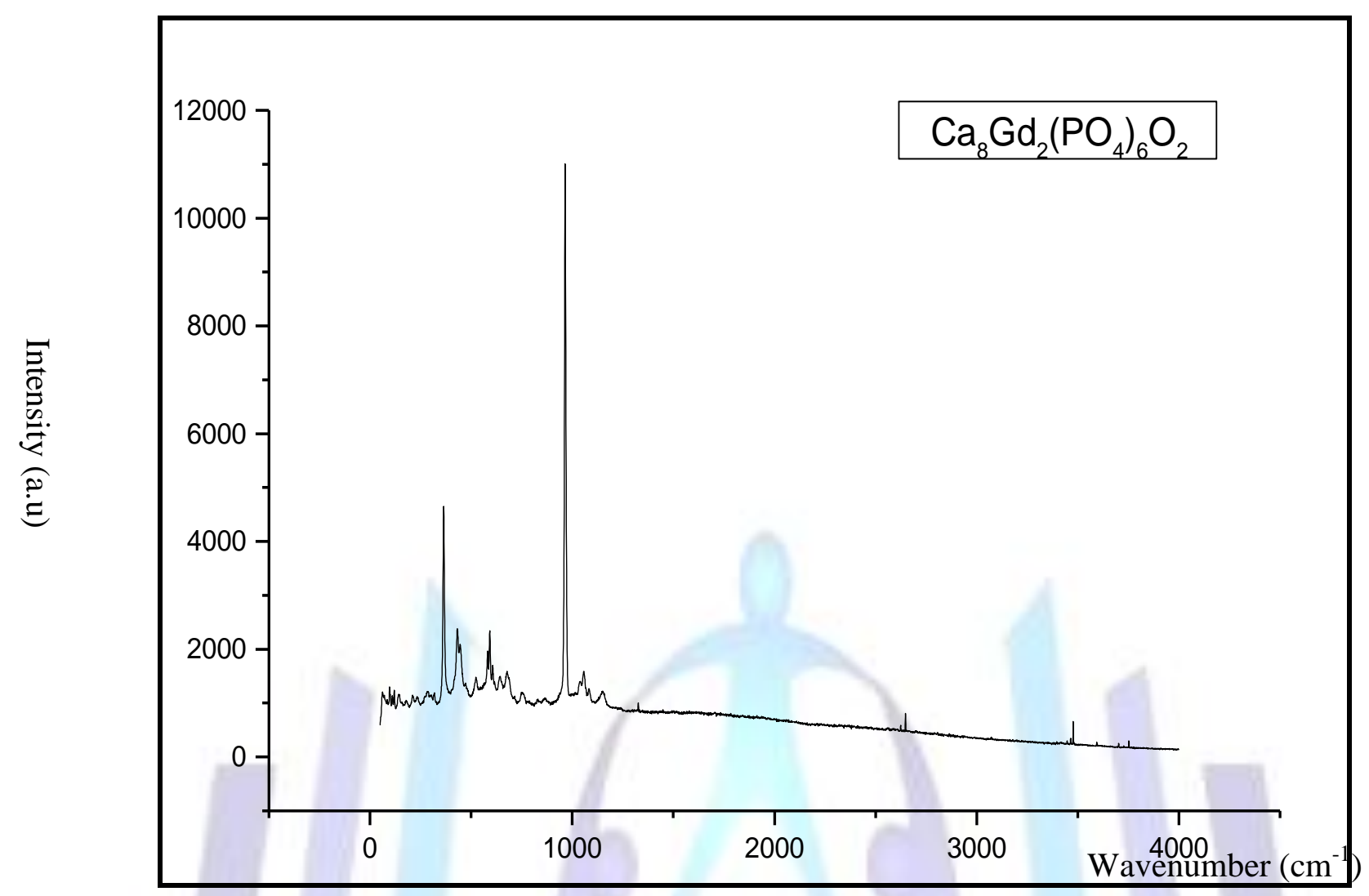

Figure. 6. Raman spectrum of $\mathrm{Ca}_{8} \mathrm{Gd}_{2}\left(\mathrm{PO}_{4}\right)_{6} \mathrm{O}_{2}$.

Table. 5. The External modes Raman and IR of $\mathrm{Ca}_{8} \mathrm{Gd}_{2}\left(\mathrm{PO}_{4}\right)_{6} \mathrm{O}_{2}$.

\begin{tabular}{|l|l|l|}
\hline Raman & IR & Assignements \\
\hline 364 & 453 & $v_{2}$ \\
445 & & \\
524 & & \\
536 & & \\
\hline 582 & & \\
593 & 571 & $v_{4}$ \\
607 & 601 & \\
642 & & \\
677 & & \\
735 & & \\
& & \\
\hline 963 & & $v_{1}$ \\
\hline 1040 & 962 & \\
1058 & 1015 & \\
1082 & 1035 & $v_{3}$ \\
\hline 3478 & 1094 & \\
\hline
\end{tabular}




\section{Conclusion}

The results from X-ray refinement has shown that the formula assigned to the new Gd substituted Ca-apatite was $\mathrm{Ca}_{8} \mathrm{Gd}_{2}$ $\left(\mathrm{PO}_{4}\right)_{6} \mathrm{O}_{2}$. The analysis of data from vibrational spectroscopy has also provided support for the high symmetry $\mathrm{P} 6_{3} / \mathrm{m}$ space group.

\section{References:}

[1] Nary Szabo, S. Z. Kristallogr. 75, (1930) 387.

[2] Mehmel, M. Z. Kristallogr., 75 (1930) 323.

[3] Kay, M. I. Young, R. A. and Posner, A. S. Nature 204, (1964) 1050.

[4] Mackie, P. E. Elliott, J. C. and Young, R. A. Acta kristallogr. Sect. B28, (1972) 1840.

[5] Elliott, J. C. Mackie, P. E. and Young, R. A. Science 180, (1973) 1055.

[6] Sudarsanan, K. Mackie, P. E. and Young, R. A. Mater. Res. Bull. 7, (1972) 1331.

[7] Hughes, J. M. Cameron, and K. D. Crowley, Am. Mineral. 74, (1989) 870 .

[8] J. M. Hughes, M. Cameron, M. and Crowley, K. D. Am. Mineral. 75, (1990) 295.

[9] Hughson, M. R. and Sen Gupta, J. G. Am. Mineral. 49, (1964) 937.

[10] Cockbain A. G. and Smith, G. V. Mineral. Mag. 36, (1967) 411.

[11] Mackie, P. E. and Young, R. A. J. Appl. kristallogr. 6, (1973) 26.

[12] Gunawardance, R. P. Howie, R. A. and Glasser, F. P. Acta kristallogr. Sect. B 38, (1982) 1564

[13] Suitch, P. R. Lacout, J. L. Hewat, A. and Young, R. A. Acta kristallogr. Sect. B41, (1985) 173.

[14] Ronsbo, J. G. Am. Mineral. 74, (1989) 896.

[15] Hughes, J. M. Cameron, M. and Mariano, A. N. Am. Mineral. 76, (1991) 1165.

[16] Wyckoff, R. W. G. Crystal Structures, $2^{\text {nd }}$ ed., Vol. 3, p. 228. Wiley, New York, (1965).

[17] Tmar, I. Madani, A. Mercier, A. M. and Toumi, M. Journal of state chemistry 197 (2013) 154.

[18] Buvaneswairie, G. and Varadaju, U. V. J. Solid State Chem. 149(2000) 133.

[19] Huang J. and Sleght, A.W. J. Solid State Chem. 104(1993) 52.

[20] Jagannathan, R. and Kottaisamy, M. J. Phys cond. Matter 7 (1995) 8453.

[21] Sudarsanan, K. Makie, P. E. and Young, R. A. Mat. Res. Bull. 7(1972) 1331.

[22] Elliott, J. C. Structure and Chemistry of the Apatites.

[23] Sudarsanan, K. Maki, P. E. Young, R. A. Mater. Res. Bull 7 (1972) 1331.

[24] Toumi, M. and Mhiri, T. Mater. Res. Bull. 43 (2008) 1346.

[25] Laghzili, A. Herch, N. El. Bouhaouss, A. Lorente, G. and Maquette, J. J. Solid State Chem. 156 (2001) 57. 